\title{
Charcoal Production as a Means of Forest Management, Biodiversity Conservation and Livelihood Support in
} Nepal

\author{
Menaka Panta Neupane, Kishor Prasad Bhatta and Suman Ghimire \\ International Union for Conservation of Nature, Nepal Country Office, P.O. Box No. 3923, Kupondole, Lalitpur, Nepal
}

\begin{abstract}
Invasive alien species (IAS) are considered as an overlooked forest resources in Nepal, despite its rapid expansion is considered as one of the main drivers of Nepal's forest degradation and deforestation. In this study, stratified systematic sampling, with nested circular plots of $500 \mathrm{~m}^{2}$, was performed in Sindhupalchowk to find out whether the removal of IAS contributes for an increase in plant diversity. Interaction with more than 310 entrepreneurs was carried to investigate the economic benefits in terms of income and employment of converting IAS into charcoal through pyrolysis in "bio-energy kilns". The study showed a higher Shannon-Weiner plant diversity index at regeneration level in IAS removed area (2.43) than that in control (1.95). Similarly, the number of seedlings and saplings was significantly higher $(P<0.05)$ in the treatment block than the number of trees in the control one. Also, the pyrolysis of 7,500 million tons (MT) of IAS in bio-energy kilns produced 1,500 MT of charcoal powder which generated a total additional income of Nepali Rupees (NRs.) 18,900,000 to 1,050 poor and disadvantaged people in 16 districts of Terai and Midhills. In spite of that, some policy hurdles, such as charcoal transportation, were observed at the operational level. It is suggested that the plant diversity could be increased through the removal of IAS, and considerable economic benefits could be achieved if charcoal is substantially produced and utilized.
\end{abstract}

Key words: Invasive alien species, forest resources, livelihood, plant diversity, charcoal.

\section{Introduction}

Charcoal is a wood fuel made from burning forest products in a low-oxygen environment. The dense black substance is made mostly of carbon and it produces more heat and energy per kilogram than wood [1]. Charcoal is the general term for a range of carbonized materials, with varying combustion and dark properties [2]. Charcoal is still an important source of energy for domestic, as well as industrial and processing applications in Nepal [3]. It is also a raw material for bio-briquette production. Previous work has even demonstrated the possibility of replacing coal and wood fuels by charcoal in industries of Nepal [4].

Sustainable forest management and biodiversity

Corresponding author: Menaka Panta Neupane, Ph.D., research fields: natural resource management and GIS. conservation have become one of the most popular topics for discussion at local, national and global level. Every forest management system prescribes several silvicultural treatments for better growth and development of forest stand and also promotes biodiversity conservation [5]. Invasive alien species (IAS) are considered native species of a specific geographical area that they have been introduced into an area out of the "typical" distribution, either by accident or on purpose (e.g., timber production), and that can "colonize" or "invade" the new area by threatening the biological-ecosystems and habitats diversity as well as the human well-being [6]. Biological invasion worldwide threatens biodiversity, ecosystem dynamics, resource availability, national economy and human [7]. Nepal has a long list of alien plant species intentionally or unintentionally introduced for various purposes. A study conducted 
by IUCN reported that over 166 species of alien plants are naturalized in Nepal [8] and add 51 species to this list from the different secondary resources, such as web sites (http://www.issg.org/database/welcome) and published literatures [9-12]. Expansion of the IAS is recorded as one of the major drivers of forest deforestation and degradation in Nepal. The high climatic and physiographic diversity make Nepal a suitable habitat for easy IAS establishment. There are 21 remarkable IAS species representing various levels of risk on biodiversity and ecosystem in Nepal [13]. These were prioritized on the basis of invasiveness character, such as Ageratina adenophora, Chromolaena odorata, Lantana camara, Mikania micrantha, Eichhornia crassipes and Ipomoea carnea subspecies fistulosa are considered as alien species with the high threat to native species and ecosystems. The various ecosystems of Terai, Chure (Siwaliks) and Midhills of Nepal are seriously threatened by IAS [14]. IUCN 2005 considers IAS as one of the greatest threats to natural ecosystems of the earth, and it is considered as the second biggest threat, after deforestation, to biodiversity conservation [15]. They disrupt the ecology of a natural ecosystem, displace the native plant and animal species, as well as degrade the landscapes unique and diverse biological resources.

The majority of alien plant species in Nepal are confined to the low lands below 2,000 m, whereas the highest concentration of endemic species (up to 91\%) occurs in a sub-alpine zone (3,000-4,000 m), particularly in central Nepal [15]. IAS is considered as an overlooked forest resources in Nepal. With several international agreements, Nepal itself formulated different policies and laws for the management of IAS. Nepal formulated its Nepal Biodiversity Strategy 2002, Nepal Biodiversity Strategy and Action Plan (2014-2020) and National Wetland Policy 2003 (revised 2012), identifying that IAS is one of the major causes for the loss of species and habitats and shows commitment to the protection and wise use of biological resources and habitats. Besides, the country has also formulated several sectorial laws (Aquatic Life Protection Act, 1961; Plant Protection Act 1972; The National Parks and Wildlife Conservation Act, 1973; Seed Act, 1988; Water Resource Act, 1992; The Forest Act, 1993; Local Self Governance Act, 1999; Agro Biodiversity Policy 2008, revised 2013) to control and eradicate the germs, pests and weeds of agricultural crops that may be native or alien species [14]. The documentation of IAS in Nepal started since 1958, however, the extension, distribution, quantity and the economic benefit that can be driven from the utilization of IAS, is scarcely known in Nepal. Mechanical removals of weeds are the immediate steps to control invasion and reduce impacts, and herbicidal applications in forest areas need to be avoided as far as possible [16]. While biological control is long term approach to controlling IAS and it is effective only to slow down the invading process [17]. But the above- mentioned techniques were rarely practiced in Nepal. The level of infestation by IAS is dependent on tree canopy cover [18]. Maintenance of high tree canopy/or under-storey vegetation of native species through different forest management activities, like thinning, pruning, cleaning, weeding, etc., can be effective approaches to minimize the invasion by IAS in forest ecosystems. Having very limited information on the importance and implication of forest management techniques, the forest user groups and other stakeholder have felt difficulties to adopt and promote such activity.

The first step of this study is to realize that sustainable use of overlooked forest resources, like IAS, can be used into charcoal through pyrolysis in "bio-energy kiln", which can play the best role in the control of invasive species. To provide baselines on the use of IAS and their impact on biodiversity and livelihood, this study aimed to display possible highlights to take into account for a possible inclusion in national policy. Hence, the paper highlights the effect of removal of IAS on plant diversity and 
considerable economic benefits to local communities.

\section{Materials and Methods}

\subsection{Study Area}

The study site, named Sindhupalchwok, lies in the hilly region of Central Nepal (27 $57^{\prime} 4.32^{\prime \prime} \mathrm{N}$ and $\left.85^{\circ} 41^{\prime} 4.56^{\prime \prime} \mathrm{E}\right)$. The total area is $2,542 \mathrm{~km}^{2}$ with an altitude variation of $300-7,080 \mathrm{~m}$ above the sea level. The site shows a wide range of climate types, from subtropical to alpine with $19.7{ }^{\circ} \mathrm{C}$ mean annual temperature and 2,500 $\mathrm{mm}$ average annual precipitation [19]. Specifically, in study site, the Bhanjan Community Forest of Attarpur VDC ward No. 8 and 9 was selected for the study (Fig. 1). The Bhanjan Community Forest lies in the subtropical climatic zone with an area of 21.25 ha. The Bhanjan Community Forest is managed by a total of 175 households. The major tree species in the forest are Castanopsis indica, Alnus nepalensis, Schima wallichi, Quercus spp., Pinus roxburghhi, Pinus wallichiana, Ficus nemarolis, Prunus cerasoides, etc.. The total forest area is divided into two different blocks, i.e., control block and treatment applied block (IAS removed block or silvicultural treatment applied block).

\section{2 Study Area for the Socio-economic Assessment}

Areas where the activities of charcoal production from IAS are implemented were selected for the socio-economic assessment. Total 16 districts from Terai and Midhills, namely: Kanchanpur, Kailali, Bardiya, Banke, Chitwan, Bara, Sarlahi, Rautahat, Makwanpur, Kathmandu, Lalitpur, Bhaktapur, Nuwakot, Kavre, Dhading, Sindhupalchowk and the charring units of the respective districts were chosen as the intensive study area.

\subsection{Plant Diversity Assessment}

Stratified systematic sampling was used for the forest resource inventory. Seven sampling plots were established in each of control and treatment applied block. The nested circular plot was established for the measurement of tree, pole, sapling and regeneration. Circular plot of radius $12.61 \mathrm{~m}$ for tree, $5.64 \mathrm{~m}$ for pole, $2.82 \mathrm{~m}$ for sapling and $1.78 \mathrm{~m}$ for regeneration were laid on the basis of Nepal National Forestry Inventory Guideline, 2061 B.S. (Fig. 2). Species wise diameter at breast height (DBH) and height were measured for tree, pole and sapling, while species wise number was recorded for the regeneration. Operation plan of community forest user groups (CFUG), inventory guideline and literatures were assessed as the secondary source of information collection.

Gini-Simpson index and Shannon-Weiner index were used to evaluate the status of plant diversity of different forest stands in both control and treatment applied block. A Gini-Simpson index $(D)$ is the modified form of Simpson index which is used for species richness within the forest stand and Shannon-Weiner index $(H)$ is used to evaluate the abundance of individual species on the forest stand, as calculated by the following Eqs. (1) and (2):

$$
\begin{aligned}
D & =1-\sum\left(P_{i}\right)^{2} \\
H & =-\sum\left(P_{i} \times \log P_{i}\right)
\end{aligned}
$$

where, $P_{i}=$ proportion of individual species in the community $i$.

For the calculation of species density at regeneration and sapling level, as well as stock density at tree and pole level, the following Eqs. (3) and (4) are used:

Species density (No./ha)

$$
=\frac{\text { number of regeneration }}{\text { area of plot }} \times 1,000
$$

Growing stock per ha $\left(\mathrm{m}^{3} / \mathrm{ha}\right)$

$$
=\frac{\text { total volume within the plot }}{\text { area of plot }} \times 1,000
$$

\subsection{Socio-economic Assessment}

A secondary source of data collection was used for the socio-economic assessment of charcoal production. This type of approach, i.e., charcoal production from IAS is in operation in 16 districts of Terai and Midhills 


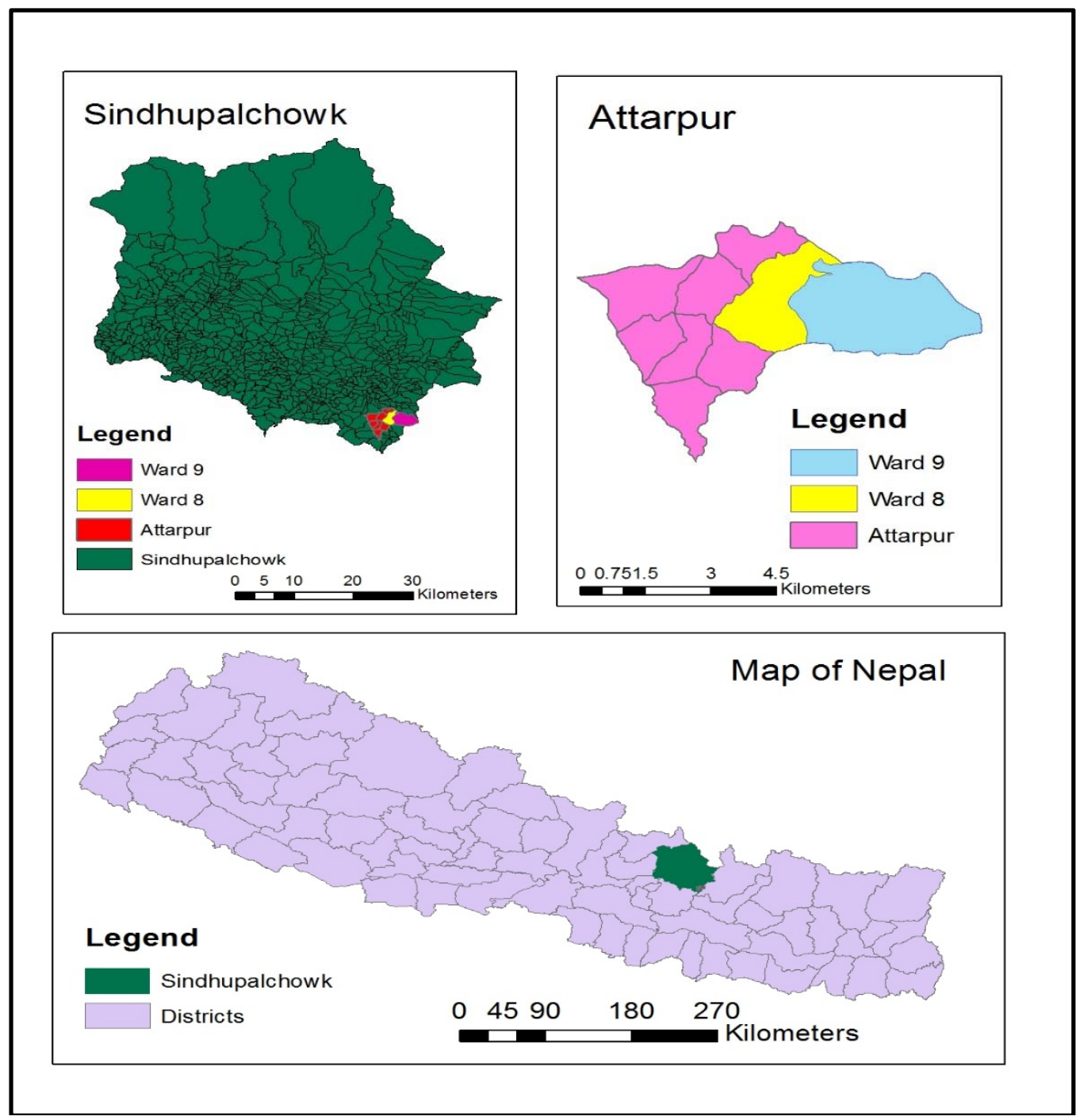

Fig. 1 Study area.

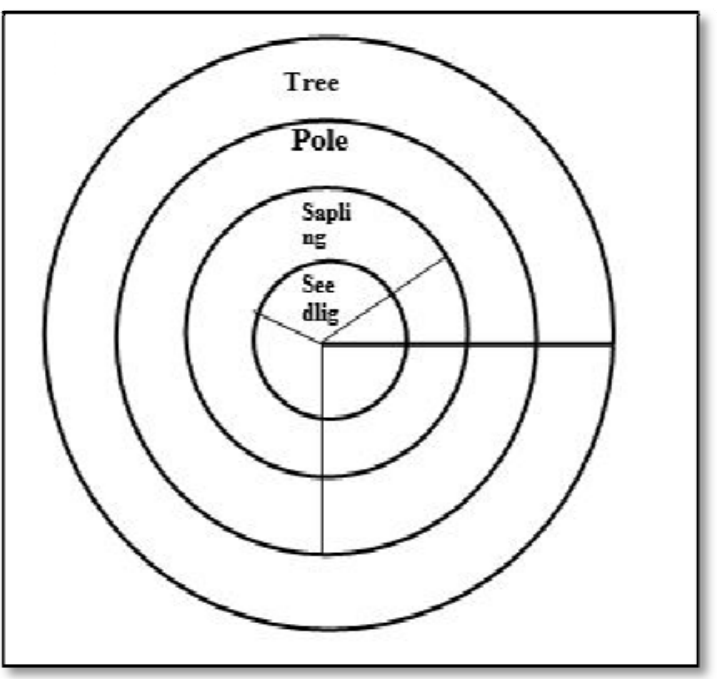

Fig. 2 Inventory plot design. of Nepal. Data were collected from the business development service providers (BDSPs), 310 charring unit and collection centers. Information regarding job availability, income and overall production of charcoal from IAS were recorded (Fig. 3).

\section{Results and Discussion}

\subsection{Plant Diversity Comparison at Regeneration Level}

The different plant diversity indexes of both site (treatment applied and control block) were shown in Table 1.

Gini-Simpson index and Shannon-Weiner index of 


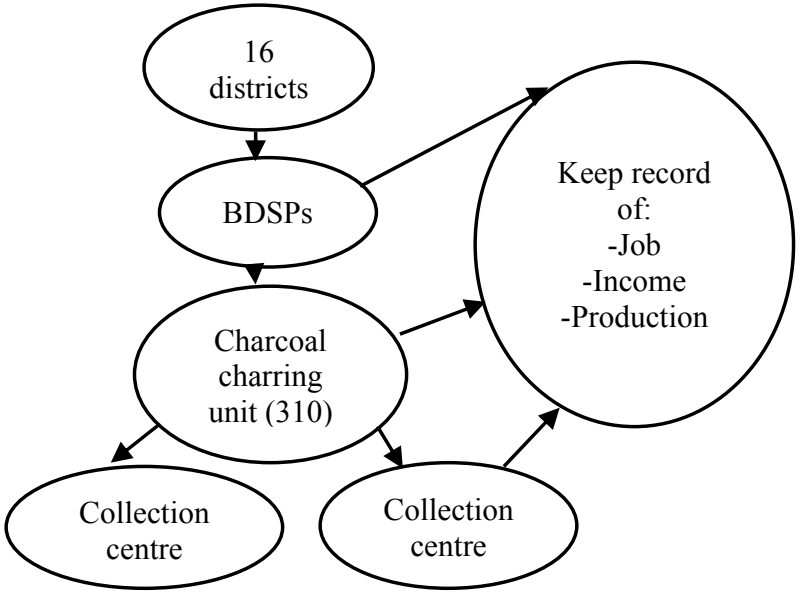

Fig. 3 Socio-economic assessment.

Table 1 Plant diversity at regeneration level.

\begin{tabular}{lll}
\hline Block & Gini-Simpson index & Shannon-Weiner index \\
\hline $\begin{array}{l}\text { Control } \\
\text { Treatment } \\
\text { applied }\end{array}$ & 0.766520 & 1.949963015 \\
\hline
\end{tabular}

treatment applied block were 0.88 and 2.43, respectively, which were higher than that of the control block. It clearly signifies that removal of IAS for charcoal production will enhance better management of forest, as well as biodiversity conservation. This result agrees with Torras and Saura [20], who stated that the managed stands had significantly higher species richness and species diversity than that in the unmanaged ones. Diversity measures of understory were significantly higher in the logged forest than that in the unlogged forest after it was performed for 10 years in beech forests of Shafarood in Guilan [21]. Similarly, some commercial and light demanding species showed significantly higher growth rates in the logged forest (treatment applied forest), with greater increment in the heavier treatment intensity [22]. Intensive silviculture treatment had the largest impact on the density and growth rates of the regeneration [23], which is similar to the findings of this study.

\subsection{Plant Density and Growing Stock Comparison}

The seedling and sapling density per hectare was found higher in treatment applied block than control block (Fig. 4), indicating that cleaning/removal of IAS contributes to the increment of plant density, because it creates the favorable environment for the germination and growth of the plant. The mean seedling and sapling densities per hectare varied significantly $(P<0.05)$ between management blocks, revealing the significance of IAS removal in promoting regeneration. While tree density was found higher in the control block than that in treatment applied block (Fig. 4), as it is directly related to seedling and sapling, but don't have a significant effect on the distribution of tree with in the short period.

Growing stock of treatment applied block was found higher than control block (Fig. 5), because more

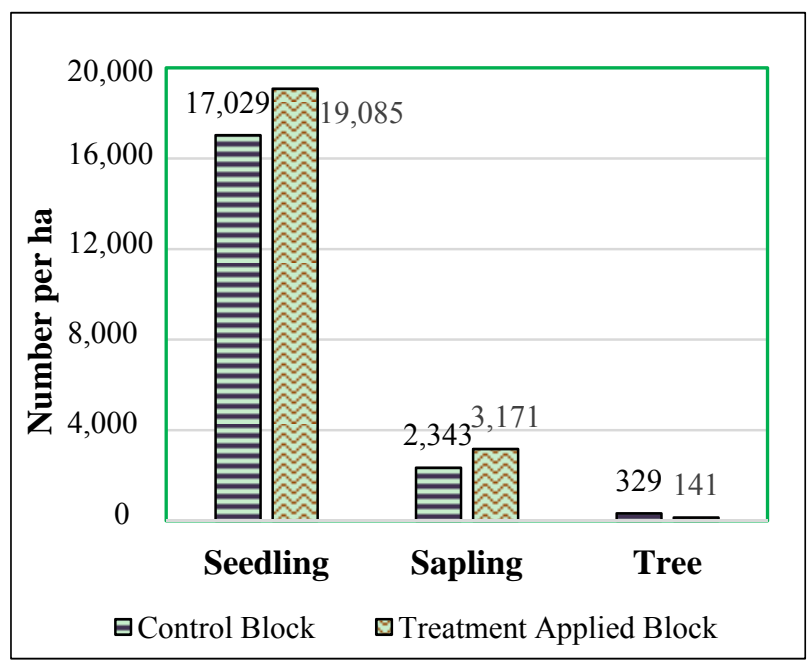

Fig. 4 Plant density.

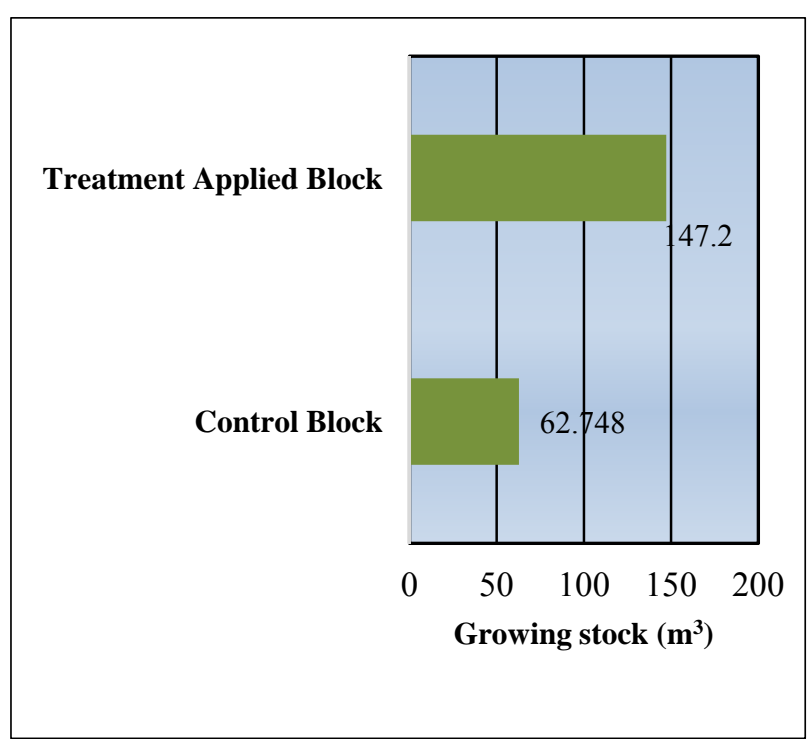

Fig. 5 Growing stock. 


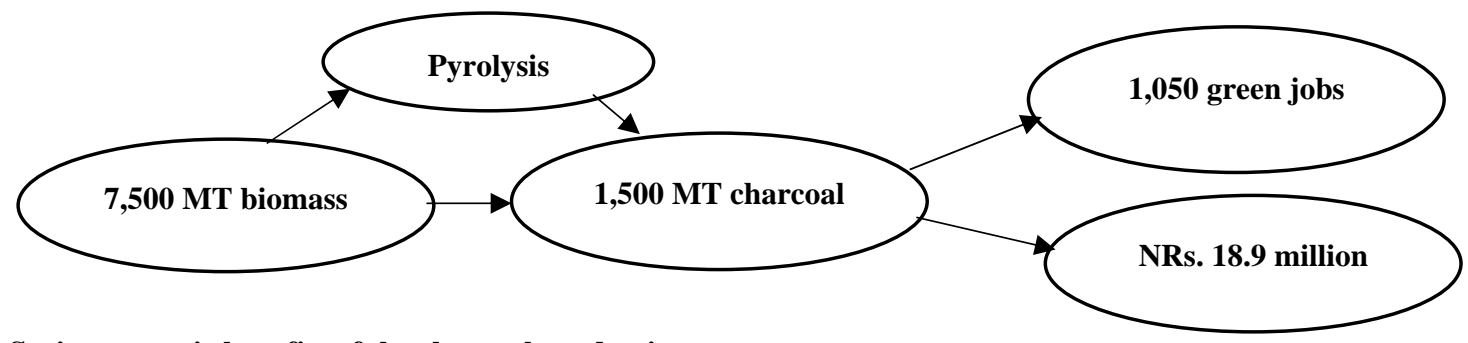

Fig. 6 Socio-economic benefits of the charcoal production.

valuable species are promoted in treatment block and forest management practices enriched the value of stumpage. Awasthi et al. [24] found higher seedling and sapling densities in the managed areas (block I and II) as compared to that in the control, i.e., unmanaged area (block III) with no regeneration felling, which could be the result of regeneration felling. However, tree density was found to be higher in the control area with 552 trees/ha as compared to the managed ones (block I with 66 trees/ha and block II with 133 trees/ha) [24], which supports the finding of this study.

\subsection{Socio-economic Benefit}

In total, 7,500 MT of biomass (IAS) was harvested in 16 districts and 1,500 MT of charcoal was produced from the above-mentioned biomass through pyrolysis process in bio-energy kiln (Fig. 6). Simply, the production ration of the charcoal from the biomass was found to be 1:5.

Pyrolysis is the heating of an organic material, such as biomass, in the absence of oxygen. Because no oxygen is present, the material does not combust, but the chemical compounds (i.e. cellulose, hemicellulose and lignin) that make up that material thermally decompose into combustible gases and charcoal [25].

From the record keeping of BDSPs and respective charring units, it was found that 1,050 green jobs were created along with income of NRs. 18.9 million from charcoal production by the pyrolysis process (Fig. 6).

\section{Conclusions and Recommendation}

According to Shannon index and Simpson index, treatment block showed higher plant diversity as well as growing stock than the control block. Seedling and sapling density per hectare was found higher in the treatment block, whereas higher tree density in the control block. Hence, sustainable harvest of IAS from the forest for charcoal production can lead to increment on forest biodiversity at regeneration level, change in forest structure, enrichment of stumpage value as well as economic benefit to local communities. Legal provision of IAS removal for charcoal production should be maintained by forest policy or related document, which can play the vital role in the control of IAS. Similarly, the provision of the royalty rate of charcoal and clear differentiation from coal on Nepal Gazette as well as registration of a charcoal unit as a small cottage industry will encourage local people towards this approach.

\section{Acknowledgements}

The authors greatly acknowledge European Union-Switch Asia Programme funded Bio-energy Project in Nepal for providing financial and technical support for this research.

\section{References}

[1] Boucher, D. H., Elias, P., Lininger, K., May-Tobin, C., Roquemore, S., and Saxon, E. 2011. "The Root of the Problem: What's Driving Tropical Deforestation Today?" Union of Concerned Scientists, Cambridge, MA. Accessed June 2011. http://www.ucsusa.org/sites/default/ files/legacy/assets/documents/global_warming/UCS_Roo toftheProblem_DriversofDeforestation_FullReport.pdf.

[2] Amanor, K., Brown, D., and Richards, M. 2002. "Poverty Dimensions of Public Governance and Forest Management in Ghana." NRSP Project R7957, Overseas Development Institute, London, and Institute of African Studies, University of Ghana, Legon. Accessed June 2002. 
https://assets.publishing.service.gov.uk/media/57a08d41e d915d622c001899/R7957FTR.pdf.

[3] Sharma, C. 2009. "Improving Charcoal Production for Sustaining the Livelihoods of Blacksmiths: Case Study of Chhisti VDC, Baglung, Nepal.” Master thesis, Rural Development, Tribhuwan University, Nepal.

[4] Prajapati, S. 2009. "Studies on the Application of Renewable Solid Fuel Alternative to the Imported Coal Fuel in Vertical Shaft Brick Kiln.” Master thesis, Institute of Engineering, Pulchowk Campus, Tribhuvan University, Nepal.

[5] Bertault, J. G., Dupuy, B., and Maître, H. F. 1995. "Silviculture for Sustainable Management of Tropical Moist Forest." Unasylva 181 (46): 3-9.

[6] Convention on Biological Diversity (CBD). 1992. Decision VI/23: Alien Species that Threaten Ecosystems, Habitats or Species (Endnote I).

[7] Riccardi, A., Steiner, W. M., Mack, R. N., and Simberloff, D. 2000. "Towards Global Information System for Invasive Species.” BioScience 50 (3): 239-44.

[8] Balakrishna, P. 2001. Alien Invasive Species: Report of Workshop on Alien Invasive Species. Global Biodiversity Forum, South and Southeast Asia Section, IUCN Regional Biodiversity Program, Asia, Sri Lanka.

[9] Siwakoti, M. 2012. "Threats and Opportunity of Invasive Alien Plant Species in Wetlands Conservation of Nepal." Presented at International Wetland Symposium, November 7 to 10, 2012, Ministry of Forests and Soil Conservation, and UNDP/GEF Project "Conservation and Sustainable Use of Wetlands in Nepal”, Pokhara, Nepal.

[10] Press, J. R., Shrestha, K. K., and Sutton, D. A. 2000. Annotated Checklist of Flowering Plants of Nepal. London: The Natural History Museum, 430.

[11] Kumar, P., Singh, P. R., and Dubedy, R. K. 2009. "Invasive Alien Species." In Souvenir of the National Conference on Invasive Alien Species: A Threat to Native Biodiversity, edited by Kumar, P. Lucknow, India: U. P. State Biodiversity Board, 5-20.

[12] Wu, S. H., Aleck-Yang, T. Y., Teng, Y. C., Chang, C. Y., Yang, K. C., and Hsieh, C. F. 2010. "Insights of the Latest Naturalized Flora of Taiwan: Change in the Past Eight Years." Taiwania 55 (2): 139-59.

[13] Ministry of Forests and Soil Conservation (MFSC). 2013. "Invasion and Colonization of Alien Species: A Threat or Benefits in Nepal." Forestry and Climate Change Cell (REDD), MFSC, Nepal. Accessed October, 2013. http://mofsc-redd.gov.np/wp-content/uploads/2013/12/In vasive-and-Alien-Species-as-Drivers.pdf.

[14] Ministry of Forests and Soil Conservation (MFSC). 2011.
Wetlands Invasive Alien Species Management Guidelines. Conservation and Sustainable Utilization of Wetlands in Nepal (CSUWN) Project, MFSC, Kathmandu.

[15] Tiwari, S., Adhikari, B., Siwakoti, M., and Subedi, K. 2005. An Inventory and Assessment of Invasive Alien Plant Species of Nepal. Kathmandu, Nepal: IUCN.

[16] Sankaran, K. V., Sajeev, T. V., and Suresh, T. A. 2014. "Invasive Plant Threats to Forests in the Humid Tropics: A Case Study from Kerala State, India." In Proceedings of the International Conference on Invasive Alien Species Management, 7-17.

[17] Sun, X. Y., Lu, Z. H., and Sang, W. G. 2004. "Review on Studies of Eupatorium adenophorum, an Important Invasive Species in China." Journal of Forestry Research 15 (4): 319-22.

[18] Chaudhary, R. N. 2015. "Status and Impacts of Invasive Alien Plant Species in the Parsa Wildlife Reserve, Central Nepal." M.Sc. thesis, Department of Botany, Tribhuwan University.

[19] Department of Hydrology and Meteorology (DHM), Government of Nepal. 2015. Weather Summary 2015.

[20] Torras, O., and Saura, S. 2008. "Effects of Silvicultural Treatments on Forest Biodiversity Indicators in the Mediterranean." Forest Ecology and Management 255: 3322-30.

[21] Pourbabaei, H., and Ranjavar, A. 2008. "The Effect of Shelterwood Silvicultural Method on Plant Species Diversity in Beech (Fagus orientalis Lipsky) Forests in Shafaroud, Guilan Province." Iranian Journal of Forest and Poplar Research 16: 61-73.

[22] Carvalho, J. O. P., Silva, J. N. M., and Lopes, J. C. A. 2004. "Growth Rate of a Terra Firme Rain Forest in Brazilian Amazonia over an Eight-Year Period in Response to Logging." Acta Amazonica 34 (2): 209-17.

[23] Pefia-Claros, M., Peters, E. M., Justiniano, M. J., Bongers, F., Blate, G. M., Fredericksen, T. S., and Putz, F. E. 2008. "Regeneration of Commercial Tree Species Following Silvicultural Treatments in Moist Tropical Forest." Forest Ecology and Management 255: 1283-93.

[24] Awasthi, N., Bhandari, S. K., and Khanal, Y. 2016. "Does Scientific Forest Management Promote Plant Species Diversity and Regeneration in Sal (Shorea robusta) Forest? A Case Study from Lumbini Collaborative Forest, Rupandehi, Nepal.” Banko Janakari 25 (1): 20-9.

[25] Boateng, A. A., and Mullen, C. A. 2013. "Fast Pyrolysis of Biomass Thermally Pretreated by Torrefaction." J. Analytical and Applied Pyrolysis 100: 95-102. 